\title{
Lysis of the Cyanobacterium Anabaena flos-aquae by Antibiotic-producing Fungi
}

\author{
By K. REDHEAD*† AND S. J. L. WRIGHT \\ Microbiology Group, School of Biological Sciences, University of Bath, Bath BA2 7AY
}

(Received 18 January 1980)

The $\beta$-lactam antibiotic cephalosporin $\mathrm{C}$ has been extracted and partially purified from liquid cultures of the fungi Emericellopsis salmosynnemata and Acremonium kiliense. The ability of these and certain other fungi to lyse cyanobacteria is attributable to the production of this antibiotic. This is supported by the similarities, seen in light and electron microscopic preparations, of Anabaena flos-aquae cells exposed to pure cephalosporin $\mathrm{C}$ and to fungal exudates.

\section{INTRODUCTION}

Several types of microbial pathogen that lyse cyanobacteria have been previously isolated and studied, including viruses, actinomycetes and bacteria (Stewart \& Daft, 1976, 1977). However, with the exception of the Chytrids (see Canter, 1972), little is known about fungal lysis of cyanobacteria.

In a previous paper (Redhead \& Wright, 1978) we described the isolation and characterization of several filamentous fungi that lysed a variety of cyanobacteria. Certain of these fungi, identified as Emericellopsis minima, Em. salmosynnemata, Acremonium charticola and Acrem. kiliense, produced heat-stable diffusible extracellular materials which inhibited growth and lysed several species of cyanobacteria. Evidence was presented that the anticyanobacterial substance could be a cephalosporin antibiotic.

Cyanobacteria have previously been reported to be lysed by antibiotics or antibiotic-like materials produced by bacteria (Granhall \& Berg, 1972; Reim et al., 1974; Burnham et al., 1976), actinomycetes (Safferman \& Morris, 1962, 1963) and fungi (Safferman \& Morris, 1962). However, in few cases has theidentity of the anti-cyanobacterial agent been established. The present study was undertaken to investigate in more detail the lysis of cyanobacteria by filamentous fungi. This paper reports on the lysis of a strain of Anabrena flos-aquae by Acremonium and Emericellopsis isolates and describes the isolation and identification of a lytic agent.

\section{METHODS}

Organisms and culture methods. The axenic culture of Anabaena flos-aquae (1403/13a) was obtained from the Culture Centre of Algae and Protozoa, Cambridge. Batch liquid cultures of this cyanobacterium $(100 \mathrm{ml}$ in $250 \mathrm{ml}$ Erlenmeyer flasks) were grown from $2 \mathrm{ml}$ inocula in mineral medium $\mathrm{D}$ plus $\mathrm{H}_{5}$ micro-elements solutions (K \& M medium) of Kratz \& Myers (1955). Cultures were incubated at $30^{\circ} \mathrm{C}$ on an orbital shaker ( 90 rev. $\mathrm{min}^{-1}$ ) and continuously illuminated (1800 lux) by warm-white fluorescent light. For $A$. flos-aquae cultures in Petri dishes, the same medium, incorporating $1.5 \%(\mathrm{w} / \mathrm{v}$ ) purified agar (Oxoid), was uniformly surface-inoculated with $1 \mathrm{ml}$ from batch cultures $(7 \mathrm{~d})$ and incubated under the same standard temperature and light regimes. These conditions were also used for maintenance of the cyanobacteria on agar slants.

The fungal cultures used were the cyanobacterial-lysing fungi Emericellopsis minima (ALF-6), Em. salmosynnemata (ALF-21) and Acremonium kiliense (ALF-62), previously isolated (Redhead \& Wright,

† Present address: Sir William Dunn School of Pathology, South Parks Road, Oxford OX1 3RE. 
1978) and deposited in the American Type Culture Collection with the accession numbers ATCC 36892, 36893 and 36894 , respectively. The fungi were maintained at $30^{\circ} \mathrm{C}$ on nutrient agar (Oxoid) and also by fortnightly subculture on lawns of $A$. flos-aquae incubated at $30^{\circ} \mathrm{C}$ under constant illumination (1800 lux).

Standard fungal inocula were prepared by applying material from fungal plaques on $A$. flos-aquae lawns to the surface of $100 \mathrm{ml}$ malt agar slants in $500 \mathrm{ml}$ flat kottles which were then incubated for $5 \mathrm{~d}$ at $30^{\circ} \mathrm{C}$. Fungal growth was removed from the agar by shaking vigorously for $2 \mathrm{~min}$ with $20 \mathrm{ml}$ sterile distilled water containing glass beads ( $4 \mathrm{~mm}$ diam.). The resulting suspension was decanted and diluted 10 -fold with sterile distilled water for immediate use as a standard inoculum which contained between 150 and $200 \mu \mathrm{g}$ dry wt fungal material $\mathrm{ml}^{-1}$.

Light microscopy. In addition to wet mounts containing mixed antagonist and cyanobacterial suspensions, two types of slide culture were used. Thinly-poured $K \& M$ agar plates were seeded with cyanobacterial suspension, inoculated with antagonist cultures and pieces of the agar were removed at intervals and placed on microscope slides for immediate examination. Glass chambers $(13 \times 9 \mathrm{~mm} \times 1 \mathrm{~mm}$ deep $)$ made on glass microscope slides were also used. The chamber was filled with molten $\mathrm{K} \& \mathrm{M}$ agar which was allowed to solidify before a mixture of the cyanobacterial and fungal suspensions was placed on the surface and the chamber was enclosed by a coverslip sealed at the edges with paraffin wax. This system could be incubated at $30^{\circ} \mathrm{C}$ for up to $5 \mathrm{~d}$ without desiccating. Samples were examined at various stages during lysis of the cyanobacteria using a Leitz Wetzlar Orthoplan microscope with phase optics.

Electron microscopy. All samples were fixed in glutaraldehyde $(3 \%, \mathrm{v} / \mathrm{v})$. Material for scanning electron microscopy was critical-point dried, sputter-coated with gold and examined in a Stereoscan S4 scanning electron microscope (Cambridge Scientific Instruments) at $10 \mathrm{kV}$.

Material for transmission electron microscopy was treated with osmium tetroxide $(2 \%, w / v)$ and embedded in TAAB (Reading) resin. Sections were cut on a Reichert OmU 3 ultramicrotome, stained with uranyl acetate and Reynolds' lead citrate and examined in a Jeol JEM 100 CX transmission electron microscope at $80 \mathrm{kV}$.

Extraction and partial purification of cephalosporin C. Nutrient broth (100 $\mathrm{ml}$ in $250 \mathrm{ml}$ Erlenmeyer flasks) inoculated with fungal suspension $(1 \mathrm{ml})$ was incubated at $30^{\circ} \mathrm{C}$ with shaking $\left(100 \mathrm{rev} \cdot \mathrm{min}^{-1}\right)$ for $4 \mathrm{~d}$. Cephalosporin $\mathrm{C}$ was extracted from $200 \mathrm{ml}$ batches of such cultures by a method similar to that described by Trown et al. (1962) based on column chromatography using Amberlite IRA-400 (acetate form; 100 to 200 mesh), Amberlite CG4B (acetate form; 100 mesh) and Dowex 50 ( $\mathrm{H}^{+}$form; X8) resins. This procedure yields a crude preparation of cephalosporin $\mathrm{C}$ (sodium salt).

Thin-layer chromatography (t.l.c.). Chromatograms were run on thin-layer plates (Kieselgel $\mathbf{H F}_{254+\mathbf{3 6 6}}$, Typ. 60, Merck, $0.4 \mathrm{~mm}$ thick) which were developed using 1-butanol/ethanol/water $(4: 1: 5$, by vol.). Cephalosporin $C$ spots were visualized under u.v. light (220 to $300 \mathrm{~nm}$ ).

\section{RESULTS}

\section{Observations on cyanobacterial lysis}

Microscopic observations of fungal plaques on $A$. flos-aquae lawn cultures showed an outer region devoid of fungal hyphae in which many cyanobacterial cells had lysed. Nearer to the centre of the plaque, fungal mycelium was intermingled with cyanobacterial cells, most of which were undergoing lysis. The centre of the plaque contained fungal mycelium and conidia with small amounts of cyanobacterial debris.

The sequence of cyanobacterial lysis was also studied using mixtures of $A$.flos-aquae cells and fungal conidia in slide culture. After $2 \mathrm{~h}$ incubation at $30^{\circ} \mathrm{C}$ many fungal conidia had begun to germinate. Within $6 \mathrm{~h}$ some cyanobacterial cells which were not in contact with the fungi began to show lysis. Vegetative cells of cyanobacterial filaments became brown-grey, and lost their distinct outline. After $18 \mathrm{~h}$ the germinated conidia had produced hyphae up to $80 \mu \mathrm{m}$ long. Cells within cyanobacterial trichomes had darkened, the cell walls were indistinct and spaces appeared between adjacent cells. Cyanobacterial filaments then began to break up and after $30 \mathrm{~h}$ had lost their linear arrangement, green colour and definition. Heterocysts did not appear to be damaged at this stage, but they eventually lost their contents and appeared as 'ghosts'.

Anabaena flos-aquae cells incubated alone in slide culture were still normal after $30 \mathrm{~h}$. Conidia incubated on $\mathrm{K} \& \mathrm{M}$ agar without cyanobacteria showed comparatively limited germination and hyphal growth.

Material for electron microscopy studies was taken from the edge of the peripheral zone 

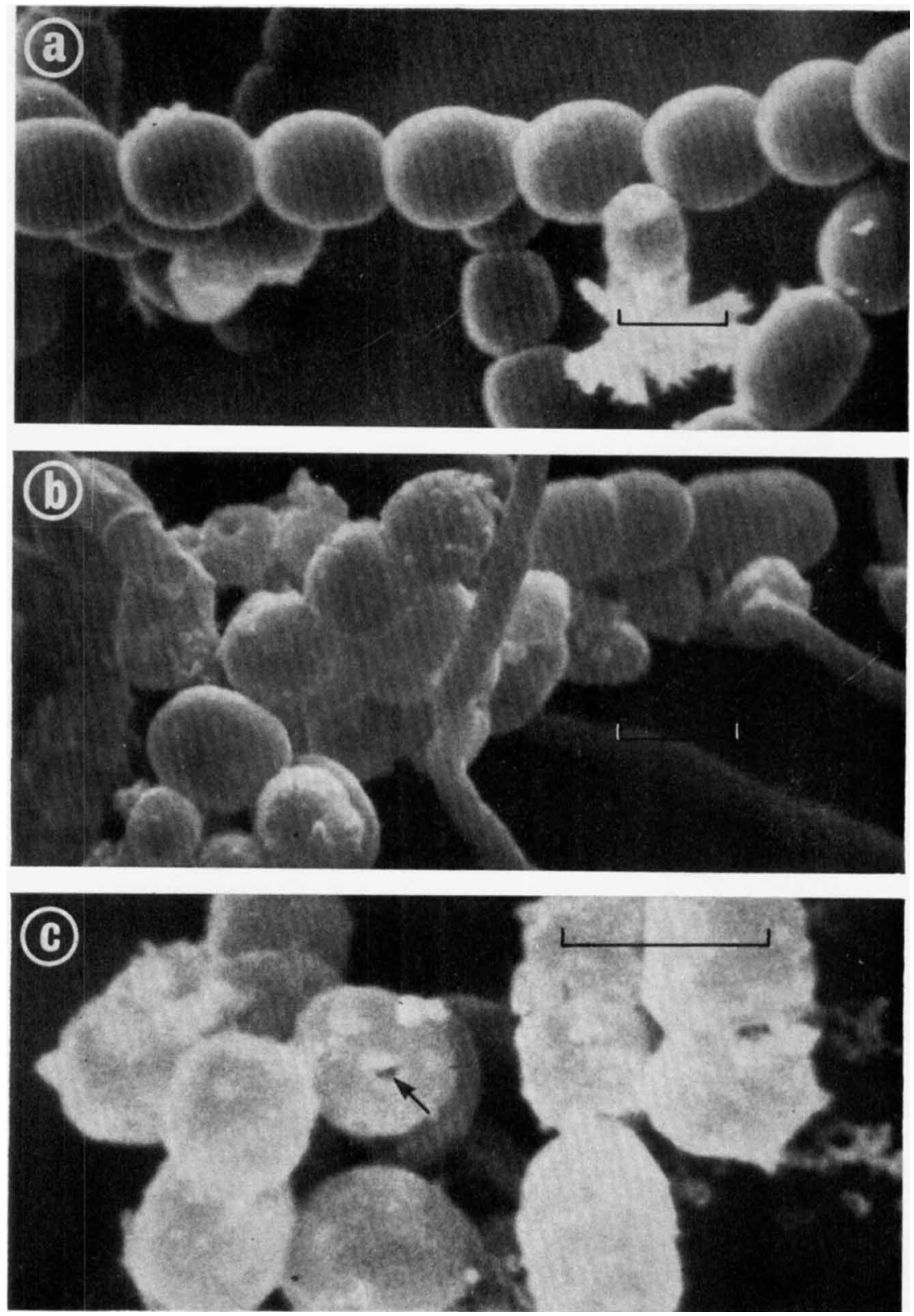

Fig. 1. Scanning electron micrographs: (a) control Anabaena flos-aquae filaments grown on K \& $\mathrm{M}$ agar; (b) A. flos-aquae filaments entangled with ALF-62 (Acremonium kiliense) hyphae, from liquid $\mathrm{K} \& \mathrm{M}$ culture; (c) A. flos-aquae cells showing pitting of the cell wall (arrowed), from the periphery of an ALF-62 plaque on $A$. flos-aquae lawn culture. All bar markers represent $2 \mu \mathrm{m}$.

of ALF-62 (Acrem. kiliense) plaques on A. flos-aquae lawns, untreated lawns, A. flos-aquae cultures (static) inoculated with ALF-62 and control $A$. flos-aquae liquid cultures.

Under the scanning electron microscope, control $A$. flos-aquae (Fig. $1 a$ ) appeared as long, regular filaments of smooth-walled cells. The entrapment of cyanobacterial filaments by ALF-62 hyphal growth in liquid culture is shown in Fig. 1(b). Scanning electron micrographs of cyanobacteria from the edge of ALF-62 plaques (Fig. 1c) showed fragmentation of the cyanobacterial filaments, with the cells in disarray. The cell walls appeared rough and in some cases were deeply pitted. 

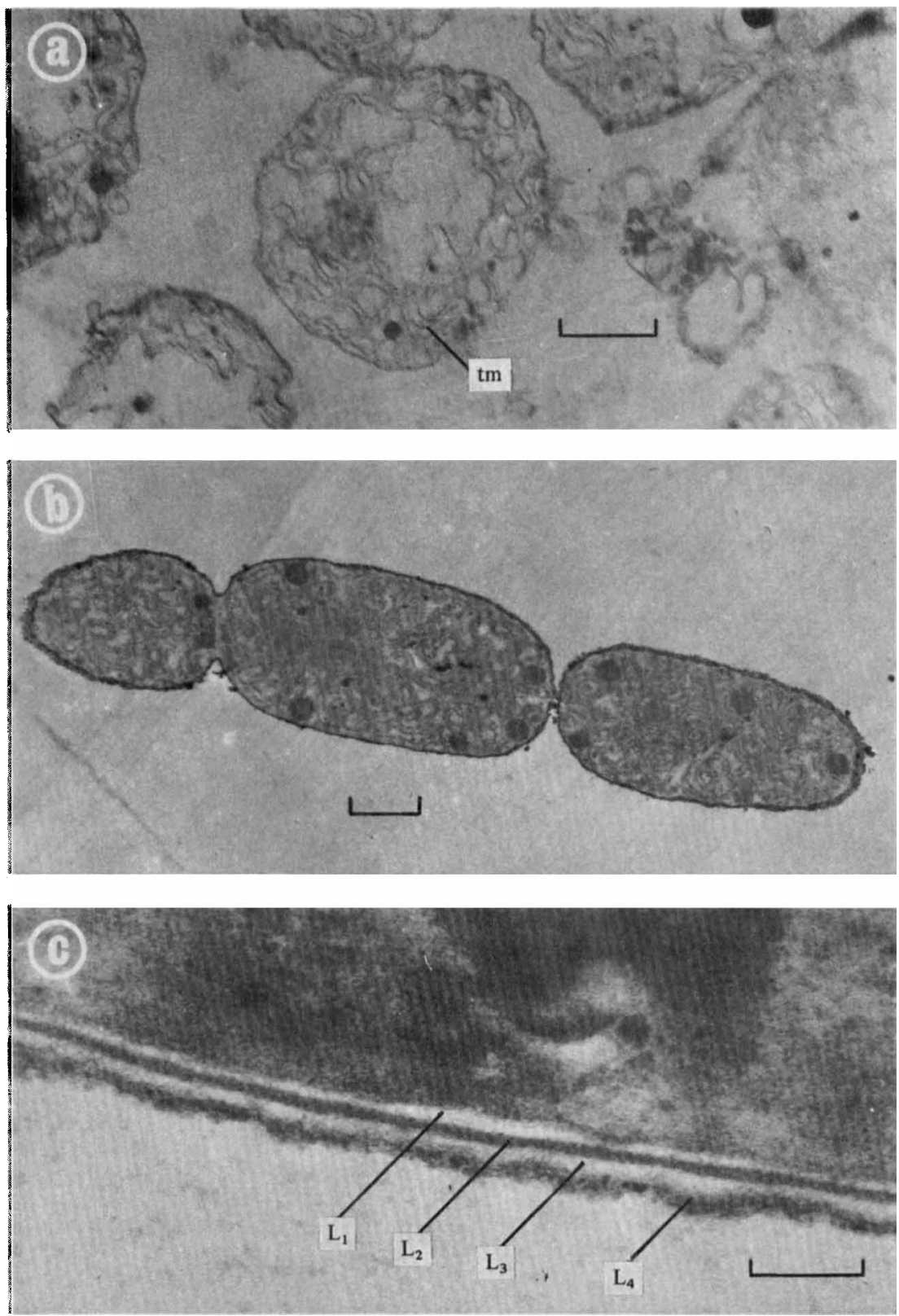

Fig. 2. Transmission electron micrographs: (a) partially lysed Anabaena flos-aquae cells, from an ALF-62 (Acremonium kiliense) plaque on A. flos-aquae lawn culture, showing folds of thylakoid membrane (tm); (b) normal $A$. flos-aquae filament; (c) section of a normal A. flos-aquae vegetative cell showing $\mathrm{L}_{1}, \mathrm{~L}_{2}, \mathrm{~L}_{3}$ and $\mathrm{L}_{4}$ wall layers. Bar markers represent $1 \mu \mathrm{m}$ in $(a)$ and $(b), 0.1 \mu \mathrm{m}$ in $(c)$.

Transmission electron microscopy showed that ALF-62 had caused loss of the wall of $A$. flos-aquae vegetative cells (Fig. $2 a$ ). Normal vegetative cells (Fig. $2 b$ ) had a regular appearance, were surrounded by a smooth wall and contained various inclusions. Detail of the wall structure (Fig. $2 c$ ) reveals the four layers $\left(\mathrm{L}_{1}, \mathrm{~L}_{2}, \mathrm{~L}_{3}\right.$ and $\left.\mathrm{L}_{4}\right)$ which are typical of cyanobacteria (Jost, 1965; Lang, 1968). After treatment with ALF-62, the wall lost its definition and the electron-dense $\mathrm{L}_{2}$ layer could no longer be distinguished. The wall eventually disappeared, leaving protoplasts containing membranous folds surrounded by the plasmalemma (Fig. $2 a$ ). These protoplasts were very similar to those produced by 
Myxobacter CP-1 attack on Nostoc piscinale (Daft \& Stewart, 1973). Lysis of the protoplasts produced folds of membranous material and the release of lipid droplets.

Lysis of $A$. flos-aquae by the fungi in liquid culture was greater under static than shaken conditions. Incubation in darkness and variation in the age of the A. flos-aquae cultures (up to $25 \mathrm{~d}$ ) did not affect their susceptibility to lysis. The extent of lysis decreased with temperature but all three fungi lysed $A$. flos-aquae cultures at temperatures as low as $15^{\circ} \mathrm{C}$ and ALF-62 had significant lytic activity even when grown at $10^{\circ} \mathrm{C}$.

\section{Identification of cyanobacterial-lysing agent}

Microscopic examination of material from the periphery of clear zones produced by the application of solutions of cephalosporin $C\left(40 \mu \mathrm{g} \mathrm{ml}^{-1}\right)$ supported earlier evidence (Redhead \& Wright, 1978) that this antibiotic could be the anti-cyanobacterial substance produced by the fungal antagonists. Cyanobacterial damage was very similar to that observed at the edge of Emericellopsis- and Acremonium-induced plaques. Scanning and transmission electron micrographs showed that vegetative cyanobacterial cells treated with cephalosporin $\mathrm{C}$ exhibited effects apparently identical to those from the edge of ALF-62 plaques (Figs $1 c$ and $2 a$ ).

Solutions were produced by immersing 30 agar cores $(0.5 \mathrm{~cm}$ diam.), removed from $1 \mathrm{~cm}$ in front of ALF-62 growth (4d) on nutrient agar plates, in $10 \mathrm{ml}$ of sterile water for $24 \mathrm{~h}$. Samples $(0.02 \mathrm{ml})$ formed clear zones $1 \mathrm{~cm}$ in diameter in $A$. flos-aquae lawns after $5 \mathrm{~d}$ incubation. These active solutions produced faint u.v. quenching spots which co-chromatographed $\left(R_{F} 0 \cdot 24\right)$ with standard cephalosporin $\mathrm{C}$ on t.l.c. plates. These results imply that small amounts of cephalosporin C, originating from the ALF-62 growth, had been extracted from the agar cores. Control solutions, using cores from uninoculated plates, showed no lytic activity or chromatography spots.

\section{Extraction of cephalosporin $C$ from fungal cultures}

The final partially purified preparation, obtained after column chromatography of ALF21 and -62 nutrient broth culture ( $4 \mathrm{~d}$ ) liquids, formed clear zones when $0 \cdot 1 \mathrm{ml}$ was applied to $A$. flos-aquae lawns. The average diameters of the zones after $5 \mathrm{~d}$ incubation were $2.0 \mathrm{~cm}$ (ALF-21) and $3.5 \mathrm{~cm}$ (ALF-62). Microscopic examination of material from the edge of these plaques showed a cyanobacterial response similar to that caused by ALF- $6,-21,-35$ and -62 isolates and by authentic cephalosporin $\mathrm{C}$.

Samples of the active preparations co-chromatographed with authentic cephalosporin $\mathrm{C}$ $\left(R_{F}\right.$ 0.24). It can therefore be concluded that ALF-21 (Em. salmosynnemata) and ALF-62 (Acrem. kiliense) produced cephalosporin $\mathrm{C}$ when grown in pure culture in nutrient broth and probably also on nutrient agar and when grown in the presence of cyanobacteria, such as $A$. flos-aquae, on agar plates, in slide culture and liquid culture.

\section{DISCUSSION}

Evidence was presented previously (Redhead \& Wright, 1978) suggesting that the extracellular cyanobacterial-lysing activity of the Emericellopsis and Acremonium isolates is associated with the antibiotic cephalosporin $\mathrm{C}$. The similarities between the effects of pure cephalosporin C and the exudates of Acrem. kiliense (ALF-62) on A. flos-aquae cells also support this suggestion. The extraction of lytic substances from agar cores containing fungal exudates which co-chromatographed with cephalosporin $\mathrm{C}$, together with the extraction and partial purification of cephalosporin $\mathrm{C}$ from Em. salmosynnemata and Acrem. kiliense culture liquids, have confirmed that these fungi produce cephalosporin $\mathrm{C}$. There seems little doubt that the lytic and inhibitory actions of these fungi on cyanobacteria are caused by this antibiotic.

The lysis of cyanobacteria by micro-organisms, other than streptomycetes, which produce 
antibiotic-like materials has been previously noted. Granhall \& Berg (1972) reported that two Cellvibrio strains produced antibiotic-like substances that caused lysis of Anabaena inequalis vegetative cells and Reim et al. (1974) attributed the cyanobacterial-lysing activity of their Bacillus brevis isolate to the production of an antibiotic, probably gramicidin $\mathrm{S}$.

Cephalosporin C is known to be produced by several Emericellopsis species (Elander et al., 1960; Korzybski et al., 1967) and by strains of Acremonium chrysogenum (Trown et al., 1962). It is believed to act in the same way as other $\beta$-lactam antibiotics by inhibiting the enzymes involved in the final stage of peptidoglycan biosynthesis, the attachment of nascent peptidoglycan to pre-existing peptidoglycan by cross-linking between the peptide sidechains. Spratt (1978) has summarized the available information on the mechanism of action of the $\beta$-lactam antibiotic penicillin on bacteria. $\beta$-Lactam antibiotics may cause changes in cell morphology, inhibition of cell division or a reduction in the peptidoglycan layer. Most of these effects eventually lead to the formation of sphaeroplasts or protoplasts which lyse in normal growth media.

$\beta$-Lactam antibiotics, such as cephalosporin $\mathrm{C}$, can be expected to act similarly on enzymes involved in the final stages of biosynthesis of peptidoglycan in the $\mathrm{L}_{2}$ layer of the cell wall in cyanobacteria. As this layer is the main rigid structural component of the cyanobacterial cell wall, the action of such antibiotics would presumably cause some variation in cell shape, and probably the production of sphaeroplasts or protoplasts. Such effects were evident in electron micrographs of $A$. flos-aquae cells exposed to both cephalosporin C solutions and to Acrem. kiliense (ALF-62) exudates.

Cyanobacteria are known to be very sensitive to penicillin, $0.02 \mu \mathrm{g} \mathrm{ml}^{-1}$ being sufficient to inhibit the growth of Anacystis nidulans (Kumar, 1964). The production of clear zones in lawns of $A$. flos-aquae by the application of $0.02 \mathrm{ml}$ of a $10 \mu \mathrm{g} \mathrm{ml}^{-1}$ cephalosporin C solution (Redhead \& Wright, 1978) further establishes the sensitivity of cyanobacteria to $\beta$-lactam antibiotics.

The Emericellopsis and Acremonium isolates probably produce small quantities of cephalosporin $\mathrm{C}$, which affect cyanobacterial cells only when they are in close proximity to the fungus, as occurs in the aggregates produced in agitated liquid culture. Several cyanobacteria, including Anabaena spp., produce sheaths of complex polysaccharides. It is possible that cephalosporin $\mathrm{C}$ produced by fungi in contact with or close to the sheath is concentrated to antagonistic levels by diffusion into this layer. The discovery that some cyanobacteria produce $\beta$-lactamase enzymes (Kushner \& Breuil, 1977) which inactivate $\beta$-lactam antibiotics suggests that these cyanobacteria may have naturally encountered $\beta$-lactam antibiotics.

Most of the experimental results in this study were obtained in vitro. However, it appears that certain Emericellopsis and Acremonium species may be present in natural cyanobacterial habitats (Redhead \& Wright, 1978) and the cephalosporin C produced by these fungi could lyse the cyanobacteria. The contribution of these fungi to the rapid disappearance of cyanobacterial blooms warrants further study.

We thank John Forsdyke for skilled assistance with the electron microscopy and photography and Dr C. H. O'Callaghan of Glaxo Research Ltd, who kindly gave pure samples of cephalosporin antibiotics. This work was supported by a Science Research Council research studentship awarded to K.R.

\section{REFERENCES}

Burnham, I. C., Stetak, T. \& Locker, G. (1976). Extracellular lysis of the blue-green alga Phormidium luridum by Bdellovibrio bacteriovorus. Journal of Phycology 12, 306-313.

Canter, H. M. (1972). A guide to the fungi occurring on planktonic blue-green algae. In Taxonomy and Biology of Blue-Green Algae, pp. 145-159. Edited by T. V. Desikachary. Madras: University of Madras.

DAFT, M. J. \& Stewart, W. D. P. (1973). Light and electron microscope observations on algal lysis by bacterium CP-1. New Phytologist 72, 799-808. 
Elander, R. P., Stauffer, J. F. \& Backus, M. P. (1960). Antibiotic production by various species and varieties of Emericellopsis and Cephalosporium. Antimicrobial Agents Annual 1, 91-102.

Granhall, U. \& BerG, B. (1972). Antimicrobial effects of Cellvibrio on blue-green algae. Archiv für Mikrobiologie 84, 234-242.

JosT, M. (1965). Die Ultrastruktur von Oscillatoria rubescens D. C. Archiv für Mikrobiologie 50, 211-245.

KORZYBSKI, T., RowsZYK-GINDIFER, Z. \& KURYLowICZ, W. (1967). Antibiotics - Origin, Nature, Properties, vol. II, P.W.N. Warsaw: Polish Scientific Publishers.

Kratz, W. A. \& MYers, J. (1955). Nutrition and growth of several blue-green algae. American Journal of Botany 42, 282-287.

KuMAR, H. D. (1964). Streptomycin- and penicillininduced inhibition of growth and pigment production in blue-green algae and production of strains of Anacystis nidulans resistant to these antibiotics. Journal of Experimental Botany 15, 232-250.

Kushner, D. J. \& BreuIL, C. (1977). Penicillinase ( $\beta$-lactamase) formation by blue-green algae. Archives of Microbiology 112, 219-223.

LANG, N. J. (1968). The fine structure of blue-green algae. Annual Reviews of Microbiology 22, 15-46.

ReDHEAD, K. \& WRIGHT, S. J. L. (1978). Isolation and properties of fungi that lyse blue-green algae.
Applied and Environmenta Microbiology 35, 962 969.

Reim, R. L., Shane, M. S. \& Cannon, R. E. (1974) The characterization of a Bacillus capable of blue-green bactericidal activity. Canadian Journal of Microbiology 20, 981-986.

SAFFERMAN, R. S. \& Morris, M. E. (1962). Evaluation of natural products for algicidal properties. Applied Microbiology 10, 289-292.

Safferman, R. S. \& Morris, M. E. (1963). The antagonistic effects of Actinomycetes on algae found in waste stabilization ponds. Bacteriological Proceedings, 14.

SpRATT, B. G. (1978). The mechanism of action of penicillin. Science Progress 65, 101-128.

Stewart, W. D. P. \& DaFT, M. J. (1976). Algallysing agents of freshwater habitats. In Microbiology in Agriculture, Fisheries and Food, pp. 63-90. Edited by F. A. Skinner \& J. G. Carr. London: Academic Press.

Stewart, W. D. P. \& DafT, M. J. (1977). Microbial pathogens of cyanophycean blooms. In Advances in Aquatic Microbiology, vol. 1, pp. 177-218. Edited by M. R. Droop \& H. W. Jannasch. London: Academic Press.

Trown, P. W., Abraham, E. P., Newton, G. G. F., Hale, C. W. \& Miller, G. A. (1962). Incorporation of acetate into cephalosporin C. Biochemical Journal 84, 157-166. 